\title{
A leitura bíblica dos pentecostais e a noção de performance
}

\section{The biblical reading of Pentecostals and the notion of performance}

\author{
David Mesquiati de Oliveira*
}

Resumo: Busca-se abordar neste texto o aspecto do fervor religioso pentecostal percebido especialmente na forma como este grupo lê a Bíblia. Tal recorte possibilitará perceber peculiaridades dessa espiritualidade e poderá contribuir para o estudo do fenômeno pentecostal. Ao contrário da maioria das formas de Protestantismo, no mundo pentecostal a noçáo da centralidade da Bíblia não ocorre preferencialmente pela via cognitiva (sistematização), mas sim pela via da experiência (sensorial), encenando as Escrituras como palavra viva, ao que chamam de "Palavra de Deus", em que os textos bíblicos são performatizados, recriando novas realidades. Essa visão gera uma preferência pelo gênero narrativo, tanto nas escolhas de leituras bíblicas quanto na pregação. Essa ação é denominada aqui de performance da Palavra e considera a forma como os pentecostais leem a Bíblia, bem como sua visão de mundo. A abordagem metodológica utilizada foi a revisão bibliográfica, passando pela discussão sobre a Estética da Recepção e a noção de performance como recurso utilizado pelo grupo em questâo.

Palavras-chave: Pentecostalismo, Performance, Estética da Recepção, Reforma.

Abstract: In this text we try to approach the aspect of Pentecostal religious fervor perceived especially in the way this group reads the bible. Such a clipping will make it possible to perceive peculiarities of this spirituality and may contribute to the study of the pentecostal phenomenon. Unlike most forms of Protestantism, in the Pentecostal world, the notion of the centrality of the Bible does not occur primarily through the cognitive path (systematization), but through the (sensory) experience, staging the Scriptures as a living word, what they call Word of God, in which biblical texts are performatized, recreating new realities. This view generates a preference for the narrative genre, both in the choices of biblical readings and in preaching. This action is referred to here as the performance of the Word and considers the way Pentecostals read the Bible as well as their worldview. The methodological approach used was the bibliographical review, passing through the discussion about Reception Aesthetics and the notion of performance as a resource used by the group in question.

Keywords: Pentecostalism; Performance; Aesthetics of Reception. Reformation.

* Doutor em Teologia. Docente do PPGCR-UNIDA. Coordenador do GP RELEP Brasil. 


\section{Introduçáo}

Busca-se abordar neste texto o aspecto do fervor religioso pentecostal percebido especialmente na forma como esse grupo lê a Bíblia. Tal recorte possibilitará perceber peculiaridades da espiritualidade pentecostal e poderá contribuir para o estudo do movimento pentecostal.

O artigo está dividido em duas partes, com três tópicos cada uma. Na primeira parte, apresenta o conceito de performance e os instrumentos dos estudos de recepção, também chamados de Estética da Recepção. Essa reflexão é importante porque esses conceitos ajudarão a identificar pistas do que seria o modo de leitura pentecostal da Bíblia. Essa parte termina com alguns apontamentos sobre o fervor religioso, tendo em vista que consideramos este elemento como o principal influenciador do tipo de leitura pentecostal.

$\mathrm{Na}$ segunda parte, aprofunda-se a caracterização da leitura bíblica pentecostal, conectando com as peculiaridades do fervor religioso pentecostal e com a noção de performance, culminando no que chamamos de leitura biblica pentecostal performáti$c a$.

\section{A noção de performance e a Estética da Recepção}

\section{A Estética da Recepção}

A Estética da Recepção (ou Estudos de Recepção) se desenvolveu a partir do final da década de 1960 e pode ser considerada "um esforço interpretativo sobre a leitura e as relaçōes estabelecidas entre texto, autor e leitor. As materialidades significativas são entendidas como um complexo que tem sentido a partir da relaçáo dialética instaurada entre o autor, a obra e seus possíveis leitores" (Adriano Filho, 2012: 176). E mais: "Toda atividade interpretativa se constitui mediante o processo de interação entre a subjetividade do leitor e as condições sócio-históricas na qual determinado signo se originou". Essa valorização da perspectiva do leitor é um contraponto às perspectivas anteriores de se avaliar ou ler um texto ancorando-se na intenção do autor: "Esta passagem ao leitor foi favorecida pela hermenêutica fenomenológica, que associava todo sentido a uma consciência. A partir da fenomenologia, várias abordagens revalorizaram a leitura, em especial a estética da recepção" (idem: 167).

A Estética da Recepção proporcionou nova forma de interpretação da obra literária ao dar uma nova orientaçáo aos estudos literários, criticando as escolas 
filológicas, estilísticas, do New Criticism e do Estruturalismo (Zilberman, 1989). O marco da virada deu-se com Hans Robert Jauss (1921-1997) em 1967, depois de uma aula inaugural na Universidade de Constança, na Alemanha. Teses semelhantes foram afirmadas por outro promotor do movimento, Wolfgang Iser (1926-2007), lançando as bases teóricas para a passagem definitiva ao leitor. A nova teoria conjugava de forma peculiar a historicidade da obra com o processo de recepção ao longo do tempo, deslocando o eixo central para o leitor. Assim, a experiência leitora do público com seus horizontes de perspectivas ${ }^{1}$ poderia construir sentidos na interação ${ }^{2}$ com as obras.

Jauss (1994) apresentou sete teses que poderiam ser resumidas da seguinte forma: 1) a relação dialógica entre o leitor e o texto é fato primordial da história da literatura; 2) na experiência literária do leitor, a obra predetermina a recepção, que é, ao mesmo tempo, um fato social dentro dos horizontes de expectativas; 3) o valor de uma obra decorre da percepção estética que ela é capaz de suscitar; 4) considerar a hermenêutica, as necessidades do público e a relação entre a literatura e a vida prática; 5) sobre o poder de ação de uma obra, que pode transpor o período em que apareceu, propóe realizar uma história dos efeitos; 6) o processo da "evolução literária" dos efeitos de uma obra destacada deve levar em conta seu momento formador e de rupturas ao longo do tempo; e, 7) a arte pode contrariar expectativas e levar o leitor a uma nova percepção de mundo, repercutindo, então, em seu comportamento social.

Quanto mais uma obra literária é capaz de afetar o universo do leitor, segundo Jauss (1994), mais forte é seu caráter emancipatório (da literatura). Esse tipo de obra produz mudanças no horizonte do leitor, conduz a uma experiência estética desconhecida até aquele momento e acaba perdurando por mais tempo que outras obras. $\mathrm{O}$ espectador pode ficar fascinado pelo que ela representa, identificar-se com as pessoas em ação, entregando-se às provocações despertadas e sentir-se aliviado, "como se participasse de uma cura (katharsis)". E continua:

Como experiência estética comunicativa básica, a katharsis corresponde à tarefa prática das artes como funçấo social. Isto é, servir de mediadora, inauguradora e legitimadora de normas de ação, quanto à determinação ideal de toda arte autônoma:

\footnotetext{
${ }^{1} \mathrm{O}$ texto e o leitor estão em horizontes históricos distintos e defasados, que precisam fundir-se para que a comunicação ocorra. Esses quadros de referência são chamados "horizontes de expectativas" e incluem as convençôes estético-ideológicas que possibilitam a produção/recepção de um texto.

${ }^{2}$ Interação entre a obra e o leitor. Wolfgang Iser afirma: "é sensato pressupor que o autor, o texto e o leitor são intimamente interconectados em uma relação a ser concebida como um processo em andamento que produz algo que antes inexistia." (ISER: 1999, 105).
} 
libertar o espectador dos interesses práticos e das implicaçôes de seu cotidiano a fim de leva-lo, através do prazer de si no prazer no outro, para a liberdade estética de sua capacidade de julgar (Jauss, 2002: 85-113).

Jauss percebeu que os leitores não são agentes passivos. Eles, portanto, deveriam ter um papel ativo na Teoria Literária. O autor retoma a dimensão da recepção da literatura e do seu efeito, em seu caráter estético e em sua função social. A novidade da abordagem de Jauss é a indicação da importância do leitor no processo de interpretação da obra literária, realçando a natureza dialógica dessa relação. Jauss afirma:

\footnotetext{
A obra que surge não se apresenta como novidade absoluta num espaço vazio, mas, por intermédio de avisos, sinais visíveis e invisíveis, traços familiares ou indicaçōes implícitas, predispóe seu público para recebê-la de uma maneira bastante definida. Ela desperta a lembrança do já lido, enseja logo de início expectativas quanto a "meio e fim", conduz o leitor a determinada postura emocional e, com tudo isso, antecipa um horizonte geral da compreensáo vinculado, ao qual se pode, entáo - e não antes disso -, colocar a questáo acerca da subjetividade da interpretação e do gosto dos diversos leitores ou camadas de leitores (Jauss, 1994: 28).
}

Com isso, superou-se a ideia de interpretação única, pois agora as obras são vistas como inacabadas e abertas a diversos olhares interpretativos (Cf. ECO, 2010). O sentido somente se consolida a partir do encontro de horizontes de expectativas, tanto dos autores quanto dos seus leitores. Em resumo, Jauss (1994) atribui à leitura uma natureza emancipatória que liberta o leitor de adaptaçôes, abrindo a possibilidade de se emancipar e empreender novas percepçóes, sentidos e interpretações para o mundo no qual habita.

No próximo tópico, busca-se introduzir o conceito de performance, que surge na esteira dos estudos de recepçáo. Essa noção performática forneceria elementos para análise da forma como os pentecostais leem a Bíblia.

\section{Performance}

A performance é uma expressão teatral ligada às artes visuais e cênicas. Diz respeito a algo que está acontecendo em dado momento, uma função do espaço e do tempo (Cohen, 2002: 28). A arte da performance surgiu para chamar a atenção do público e faz uso de algumas técnicas, como luz, tato, imagens, som, para atingir diversos sentidos do espectador e fazê-lo inserir-se no drama (Glusberg, 1987). 
A ideia da performance, no entanto, não é totalmente nova. Na realidade, ela remonta-se à Antiguidade, quando o ser humano se tornou consciente de si mesmo, sendo a autoconsciência a primeira arte, ou mesmo a própria Arte, conforme defende Renato Cohen (2002: 16). Mas só recentemente "a performance começa a impor-se como linguagem", constituindo um novo gênero (idem: 21). Neste gênero, há espaço para o imagético, para o não verbal, abrindo espaços para tratativa e enfrentamento de temas existenciais e processos de construçáo cultural mais irracionais, para além do que a linguagem descritiva poderia levar e além do convencional. Isso não reduz a performance à condição de mero improviso ou carência de lógicas acadêmicas, mas diz que está na fronteira, que rompe convençóes, formas e estéticas (Cohen, 2002: 26). Trata-se de uma linguagem híbrida que proporcionaria "muito mais eficácia de comunicação que as linguagens estéticas da arte" (idem: 164), pois não está centrada no suporte (livro, tablet, smartphone), mas na dialética do conteúdo para a vida do indivíduo ou da comunidade.

Uma característica importante da performance é seu carácter coletivo ou inclusivo. Ainda que aparentemente haja somente uma pessoa desenvolvendo sua performance, na verdade, da maneira como o faz, integra os espectadores ao drama, de tal forma que todos podem fazer parte da cena, sendo que, neste caso, não há expectadores, mas atuantes (idem: 29). A esse tipo de performance Cohen denomina de performance cênica ritual, para diferenciar da performance cênica estética em que, sim, incluiria a apresentação para expectadores (idem: 113-140).

Aplicar essa noção de performance dramática à leitura vai ao encontro da valorização da perspectiva do leitor. A leitura performática ultrapassa o viés semiótico ao incorporar outros horizontes. Graciela Ravetti (2003) afirma:

\footnotetext{
[...] a performance revela experiências que fazem o percurso do pessoal ao comunitário e vice-versa. Esse trânsito está fortalecido por um impulso de resistência à dissolução de componentes culturais e ideológicos que atuam como resíduos culturais que integram as pessoas à uma regiáo, à uma paisagem, e que passam a ser pele, olhos, roupa, gestos, fala, em partituras que se percebem como resto de algo maior e irrecuperável, reproduzido e passível de ser re-escrito, mas que de alguma forma deve ser restituído a um passado e, ao mesmo tempo, transmitido ao futuro e relido no presente (Ravetti, 2003: 83).
}

A leitura performática não fica presa ao conhecido e decodificado, mas pode avançar e incorporar suspeitas, intuiçóes e experiências pessoais. A ideia de um leitor com função autor desestabiliza a noção tradicional de autor como o princípio de uma certa unidade de escritura. A performance possibilita a mescla entre vivência e 
ficção e entre texto e biografia pessoal. Luciene Azevedo destaca que "a performance narrativa é tanto uma instância que baralha a correspondência entre o vivido e o inventado, confundindo o enredo ficcional com informações biográficas como uma estratégica capaz de assegurar ao narrador assumir uma pluralidade de vozes" (Azevedo, 2007: 138).

A performance está relacionada com a historicidade inerente ao gesto ou à fala. Ela personifica citaçóes de outros discursos, de outros gestos, adquirindo um caráter de identidade instável, fugitiva (IDEM). É uma repetição estilizada, mas que "o modo de atuação da performance implica não apenas a 'imitação' de uma pretensa autenticidade autoral, mas também seu deslocamento e ressignificação" (idem: 139). A performance implica releituras e, quanto mais um texto for lido, mais rico ficará, pois integrará novos aspectos de conteúdo: "O histórico deixa de ser o passado, tornando-se o mundo que cerca os leitores e dá a eles a capacidade de acessar 'mundos e fundos' inacessíveis, por exemplo, à audiência original" (Terra, 2016: 874).

A noção de performance pode ser muito útil para o estudo do Pentecostalismo, pois, além das expressóes corporais e cênicas, há não só uso de citações de outros discursos, mas a personificação destas citações, uma relação direta com pouca ou nenhuma mediação institucional. Para esclarecer melhor essa questão, faz-se necessário pontuar o específico do fervor religioso dos pentecostais. A partir daí, começar a identificar as formas performáticas dos pentecostais.

\section{O fervor religioso pentecostal como condicionante da performance}

Antes de tratar do tema do fervor pentecostal, buscaremos esclarecer o tema do fervor religioso em seu sentido lato. Max Weber observou que o fervor religioso condiciona, inclusive, os parâmetros e os utensílios eclesiásticos de todo tipo, sejam os objetos artísticos nos serviços religiosos ou mesmo a arquitetura dos templos, fazendo com que a religião se torne uma fonte inesgotável de possibilidades artísticas e de estilização (Waizbort, 1995: 30). Jon Witt (2016) analisa a questão da experiência religiosa a partir de Max Weber (eclesiae e seita) e enfatiza que nos grupos tipo seita ("igreja de fiéis"), a pertença se baseia "na aceitação consciente de um dogma religioso". E acrescenta: "Ao contrário das eclesiae e das denominaçóes, [as seitas] exigem compromissos intensivos e demonstraçóes de crença por parte de seus membros. Em parte, por não pertencerem ao campo predominante, as seitas frequentemente apresentam um maior grau de fervor religioso e lealdade do que os 
dos grupos religiosos mais estabelecidos" (Witt, 2016: 197-198). Daí advêm duas características muito comuns nesses grupos, que são as de ser missionário ${ }^{3}$ e conversionista ${ }^{4}$.

Com o tempo, as seitas tendem a desaparecer ou a se institucionalizar, podendo migrar para a condição de denominação. A denominação seria a religião grande e organizada e que náo é oficialmente vinculada ao Estado ou governo. Ao que tudo indica, há uma proliferação de novos grupos com intenso fervor religioso. Em $O$ enigma da religiāo, Rubem Alves escreve:

Uma chuva de novos deuses começou a cair e um novo aroma sagrado encheu espaços e nosso tempo. Não se pode contestar que as formas cristalizadas e institucionalizadas da religiáo estáo em declínio - crises estruturais da totalidade dos grupos religiosos organizados. Por outro lado, entretanto, não se pode negar o surto de um novo fervor religioso assumindo agora formas novas, inesperadas e bem pouco institucionalizadas. Durkheim, se estivesse vivo, sorriria ao ver a sua curiosa previsão se cumprir: "os velhos deuses estáo ficando velhos ou já morreram e outros ainda não nasceram (...) Um dia virá quando as nossas sociedades conhecerão de novo horas de efervescência criadora, no transcorrer das quais ideias emergem e novas fórmulas são encontradas, que servem, por um pouco, como guias da humanidade" (Alves, 2007: 167).

Não somente temos o fenômeno religioso muito presente e atuante em vários aspectos da sociedade brasileira e latino-americana, senão que é possível observar um novo fervor religioso e sob novas formas. Sobre essas contradições da secularização do mundo, Peter Berger (2001: 10) afirma:

\begin{abstract}
Algumas instituiçóes religiosas perderam poder e influência em muitas sociedades, mas crenças e práticas religiosas antigas ou novas permaneceram na vida das pessoas, às vezes assumindo novas formas institucionais e às vezes levando a grandes explosōes de fervor religioso". E continua: "Inversamente, instituiçôes religiosamente identificadas podem desempenhar um papel social ou político mesmo quando poucas pessoas confessam ou praticam a religiáo que essas instituiçóes representam.
\end{abstract}

Essas afirmaçôes denunciam o quão complicada e complexa é a relação religiãosociedade, e como as crenças e as práticas religiosas sob novos formatos institucionais podem produzir explosóes de fervor religioso.

\footnotetext{
${ }^{3}$ Missionário ("enviado") no sentido de que os membros desses grupos se sentem, muitas vezes, como que enviados para todas as pessoas para compartilhar com elas a sua explicação de mundo. É a dimensão do anúncio público da fé.

${ }^{4}$ A conversão é uma ruptura com o estilo de vida anterior combinado com a adoção de novas formas de comportamento.
} 
Larry Furtado (2011) afirma que o fervor religioso sempre caracterizou a forma de culto dos diferentes grupos das igrejas do século I. Ele chega, inclusive, a dizer que esse fervor teria sido a característica atraente e importante dos cultos cristáos. As narrativas desse período incluem com frequência, justamente por conta desse fervor, experiências de êxtase, de profecia e de curas. A adoração cristá, no começo, foi impregnada de fervor especialmente devido à ideia dos dons divinos (chamados de dons do Espírito Santo) que conferiam às práticas cristãs daquele tempo um caráter carismático (carismas do Espírito), juntamente com outros conceitos e afirmações religiosas. "Fica evidente", afirma Furtado (2011), "que a exuberância, a alegria, a sensação de encontro com o divino e até mesmo um forte êxtase religioso eram, não raro, buscados pelos devotos e cultivados de várias maneiras nos cultos". Na falta de cerimônias sofisticadas e de templos imponentes como eram os das outras religióes contemporâneas, aquelas experiências fervorosas cobraram ainda mais força.

Os pentecostais, por sua vez, surgem no final do século XIX e início do século $\mathrm{XX}$ das fileiras protestantes, especialmente dos metodistas e batistas estadunidenses, mas também conectados com outras regióes do globo. Havia entre eles alguns movimentos que ficaram conhecidos como Grandes Despertamentos (revivals). Antonio Gouvêa Mendonça (2008) faz uma breve avaliaçáo dos mesmos e conclui que foram movimentos de avivamento do fervor religioso, surgidos em diversos lugares e por meio de grupos religiosos distintos. No século XVIII, o primeiro desses movimentos contou com conversóes em massa envolvendo diferentes igrejas, como o caso de Jonathan Ewards, por exemplo, calvinista e congregacional, mas também com George Whitefield (metodista), além de alguns presbiterianos e parte dos puritanos. Nos séculos seguintes, a mensagem metodista arminiana acabou tendo alcance maior, pois se dirigia a todos, enquanto que a calvinista buscava os eleitos, sem contar a questão da intelectualização e da formalidade dos presbiterianos (Mendonça, 2008: 84).

Nesse reavivamento do fervor religioso abria-se espaços para posturas restauracionistas, que buscavam reviver a igreja do começo, dos tempos do Novo Testamento. Nesse afá, alguns grupos começaram a ler a Bíblia e buscar respaldo para suas experiências, de um lado, e, de outro, ao ler essas experiências extáticas do século I, queriam revivê-las no presente. Como a narrativa do evento de Pentecostes no livro de Atos dos Apóstolos era mais vívida e imprimia um ar de profecia e de extensão ao futuro, despertou nesses novos crentes no século XX um desejo de reviver o Pentecostes do século I. Bernardo Campos, teólogo pentecostal peruano, enfatiza que o Pentecostes, com tudo o que significou para fé cristã e para a igreja no início, é 
encarado pelos pentecostais como normativo para a igreja cristá, que busca experimentar o que está narrado nas páginas do Novo Testamento (Campos, 2002: 88). Donaldo Dayton (1991) corrobora essa afirmação e acrescenta que os pentecostais do início do século XX se identificavam como os que pregavam o Evangelho pleno, isto é, os quatro pontos centrais: "Jesus salva, cura, batiza com o Espírito Santo e em breve voltará”. Essa seria a chave teológica para entender a mensagem do grupo. Anunciavam um Cristo que intervém milagrosamente na vida das pessoas dando-lhes a certeza e a alegria da salvação, mesmo em meio a tantos problemas e limitaçôes. Aqui se insere o segundo quadrante, com curas e milagres, que seriam os sinais de que o reino de Deus estaria entre eles. O terceiro quadrante indica o específico do pentecostal, a doutrina do batismo com o Espírito Santo, uma experiência mística, intensa, que deveria vir acompanhada de glossolalia (línguas estranhas, sejam idiomas existentes ou línguas ditas angelicais, de outra ordem). Essa característica daria aos cultos pentecostais um vigor novo. Por último, a pregação sobre a esperança, sobre a vida futura, por meio de tão farto material apocalíptico na Bíblia (Dayton, 1991).

Ainda hoje os pentecostais guardam essas experiências fervorosas, sendo mais visíveis em algumas congregações do que em outras. ${ }^{5}$ A questão que se levanta é: como esse fervor renovado e informado pelo Espírito Santo (na ótica pentecostal) condiciona a leitura bíblica pentecostal? Buscaremos apresentar alguns elementos.

Em uma reportagem no jornal "Folha de São Paulo", Leandro Beguoci (2007) apresenta os resultados de pesquisas comparadas da realidade de dez países realizadas por institutos dos EUA. Entre os dados apresentados, Beguoci enfatiza: "Apenas em um item abre-se um abismo entre os pentecostais e as outras pessoas: o fervor religioso. Entre os entrevistados pela Pew Forum, 86\% dos pentecostais dizem que váo à igreja ao menos uma vez por semana. Na população como um todo, o dado cai para 38\%” (Beguoci, 2007 [n.p.]). E continua: "Quando o assunto é leitura da Bíblia, 51\% dos pentecostais dizem ler o livro sagrado todos os dias, contra apenas 16\% das demais pessoas".

Assim, o fervor religioso dos pentecostais influencia não só a frequência e a disciplina de leitura da Bíblia, mas também a forma de ler, a hermenêutica. Intentase desenvolver essa ideia na segunda parte.

\footnotetext{
${ }^{5}$ Marcela Cintra, a partir da área da Comunicação, registrou 30 imagens para aproximar duas experiências religiosas aparentemente antagônicas. Em seu trabalho de Fotojornalismo, ela buscou o ponto comum entre dois grupos religiosos que expressam sua religiosidade de forma intensa por meio da corporalidade, como os pentecostais e os praticantes do Candomblé: o fervor nos cultos, ao que ela chamou de "performance de fé". Em sua obra, ela buscou registrar as "expressôes corporais táo fervorosamente sentidas por cada fiel ao encontrar seu deus" (Cintra [s.d.]).
} 


\section{A Leitura bíblica dos pentecostais}

\section{O Pentecostalismo no Brasil e a leitura bíblica}

Os pentecostais estariam vinculados aos protestantes não só porque formaram igrejas a partir deles, mas porque, de forma análoga ao Protestantismo no século XVI, buscavam "um retorno às origens do cristianismo" (Passos, 2005: 31). Quase 400 anos depois do início do movimento protestante, os pentecostais fazem seu próprio retorno às Escrituras, mas, desta vez, lendo-a na perspectiva do Espírito, da mística e do milagre. ${ }^{6}$ Os dois movimentos estavam buscando reformar a igreja por meio de um retorno às origens, especialmente do lugar das Escrituras como regra de fé.

No Protestantismo, esse retorno às Escrituras significou o protagonismo da teologia paulina, por meio dos livros bíblicos de Romanos e outras epístolas, desencadeando a preocupação com a reta doutrina (ortodoxia). Com isso, fez duras críticas à estrutura da Igreja e desencadeou uma reforma mais ampla. Já o Pentecostalismo, em movimento similar ao misticismo medieval ${ }^{7}$, buscou uma reforma da igreja por meio da intensidade da fé e da experiência religiosa. Os textos que ganharam proeminência eram os de perspectiva lucana, como os livros de Lucas e Atos dos Apóstolos, que foram instrumentalizados para se retornar a uma espiritualidade mais intensa, nos moldes do antigo Pentecostes e ampliando as experiências extáticas.

O acesso à Bíblia como "Palavra de Deus" - termo com o qual os cristãos em geral denominam as Escrituras judaico-cristâs tidas como sagradas - ocorre de modo diferente entre os pentecostais, se comparado com os protestantes. A via preferida pelos pentecostais não se dá por meio da escolarização ou da intelectualização da fé, mas por meio de experiências místicas com o texto (diretamente ao sujeito), que é entendido como Palavra de Deus direta ao indivíduo e à comunidade. O Pentecostalismo, pensado como entidade, utilizou a seu favor a descoberta do sujeito na Modernidade, bem como a consequente subjetividade e valorizaçáo da experiência, que entrou em voga na contemporaneidade. As Escrituras são tidas em alta estima nas comunidades de fé pentecostal e são consideradas base de fé e prática, como

\footnotetext{
${ }^{6} \mathrm{~A}$ isso os pesquisadores pentecostais têm chamado de "hermenêutica do Espírito" (Keener, 2016; Campos, 2016; Archer, 2009; Martin, 2013; Noel, 2010).

7 Walter Altmann (1994, p. 31) considera que o misticismo "renunciou à pretensão de reforma eclesiástica, ou pelo menos a colocou em segundo plano. O necessário revigoramento foi buscado não na açáo sobre estruturas externas, mas antes no interior das próprias pessoas, através de uma renovação da fé, da experiência religiosa e da piedade".
} 
ocorre na maioria dos grupos cristáos, com a insígnia da elevada quantidade de leitura pessoal, conforme apontado no tópico anterior, motivado pelo fervor religioso pentecostal. O viés da experiência confere uma distinção a essa relação com o texto sagrado, pois que promove interiorizaçáo e apropriação da Palavra (oralizada e performatizada) e ao mesmo tempo, projeta a Palavra para o exterior, ressignificando o mundo ao seu redor. Náo é uma simples privatização da Escritura como foro íntimo, para fazê-la acomodar-se aos padróes possíveis do indivíduo (por mais que isso possa ocorrer), mas é a atitude de assumir essa Palavra existencialmente na "força do Espírito", como diriam os pentecostais, a tal ponto que ela governe a vida do fiel, reorientando-a aos ditames exauridos do texto sagrado, tornando essa Escritura um tipo de texto encarnado ou dramatizado (performance).

Esse apego ao "texto sagrado vivo" está carregado de misticismo em seu subjetivismo, mantendo, de forma específica no meio pentecostal, o espírito da Reforma (Sola Scriptura). Em situaçóes desse tipo, o sagrado e o secular se interpóem. A fé ultrapassa o templo (fanum), o sagrado invade o mundo e a existência, ou como diria Tillich (2009: 161-175) a partir do existencialismo, seria como se o ser de Deus se apresentasse nos seres humanos.

Sob influência dos avivamentos americanos e europeu, o Pentecostalismo brasileiro criou escolas bíblicas, e depois os institutos bíblicos ${ }^{8}$. A questão central era como aplicar a leitura do texto sagrado à pregação e à vida. A leitura da Bíblia veio a se caracterizar pelo contexto do indivíduo/grupo. Não é uma leitura tipicamente sistemática ou analítica, ou, para discutir diferentes abordagens filosóficas, por mais que também existam tais leituras. Antes, essa leitura parte de um "cânon dentro do cânon" ou sedimenta esse cânon seletivo. A preferência dos pentecostais, como apontado no tópico anterior, foi pela teologia narrativa de Lucas, mas incluía perícopes variadas, tanto do Antigo como do Novo Testamento, com alusões ao fenômeno do Espírito. O texto de Atos dos Apóstolos se transformou em uma espécie de carta magna para as igrejas pentecostais e um modelo a ser emulado, normativo. Em Atos, a ênfase está no Cristo ressurreto que ascendeu aos céus, mas que enviou o Espírito Santo (grego Paracleto, “o Consolador”), que faria a união mística entre o ser humano e Deus. Na teologia lucana, antes de ser o ressurreto, o Cristo foi Jesus de Nazaré, o "Filho do Homem", expressão muito comum em seus textos. Esse enviado de Deus tinha como missão anunciar o reino de Deus, que era a concretização da justiça e da paz no imaginário dos cristãos do

\footnotetext{
${ }^{8}$ Gedeon Alencar (2013) destaca a opção do Pentecostalismo brasileiro pelos institutos bíblicos em detrimento dos modelos de seminários teológicos ou de faculdades.
} 
começo. Roger Stronstad (1984) propôs que Lucas fez mais que narrar histórias em seus textos, dado a tendência racionalista de diminuir seus escritos frente aos paulinos. Stronstad esforçou-se para mostrar que há uma teologia narrativa de Lucas e que teria sua contribuiçáo para a construçáo do pensamento teológico atual.

A leitura bíblica adquiriu um efeito poderoso nas comunidades pentecostais. Ler a Bíblia completa e sequencialmente de Gênesis a Apocalipse tornou-se um alvo almejado e sinônimo de espiritualidade sadia. Contudo, se o fiel não pudesse ler por alguma razão, ao menos o cânon dentro do cânon teria que dominar e até decorar trechos para recitação. Essa é outra forma do texto ganhar vida na perspectiva do fiel, criando uma relaçáo pessoal direta. Talvez por isso sejam táo valorizadas as citaçóes de textos bíblicos (memorizadas) durante as celebraçóes, especialmente na pregação, em que se faz intenso uso de citaçóes diretas de textos bíblicos.

Mas, apesar de ser um alvo, observa-se que a leitura sequencial e completa da Bíblia está menos frequente, apesar de estar acima da média nacional, conforme dados apresentados anteriormente. Contudo, é ainda um hábito muito comum. ${ }^{9}$ Isso porque a leitura precisa tocar-lhes o "coração", semelhante ao que sei observava no Pietismo alemáo do século XVII e aos ensinos de John Wesley, pai do Metodismo inglês e norte-americano, que muito influenciou o movimento pentecostal mundial. Defendem que é possível - e de fato necessário em sua

\footnotetext{
${ }^{9}$ Eu nasci em um lar pentecostal (Assembleia de Deus) e permaneço nesta denominação até hoje. Lembro que desde criança éramos ensinados a ler diariamente a Bíblia. Meu pai trabalhava em uma fábrica de celulose no interior do Estado do Espírito Santo e saía cedo todas as manhãs para regressar à tarde. Cresci, juntamente com muitos amigos de minha geração, tendo um culto doméstico ao final do dia com toda família, em que se conversava sobre a leitura bíblica do dia e de forma comunitária, fazia-se aplicaçóes pessoais. Quando cheguei à adolescência, já tinha lido a Bíblia inteira algumas vezes. Minha mãe, embora tivesse vindo do interior, onde recebeu sua educação em escola rural equivalente ao atual Ensino Fundamental I, chegou a ler a Bíblia completa e sequencialmente mais de quarenta vezes, mantendo uma disciplina diária. Sua Bíblia era toda marcada, com versículos em cores distintas e anotaçóes nas laterais e em cadernos especialmente separados para isso. Ela faleceu jovem, com 55 anos de idade, mas quando contava suas experiências com a leitura bíblica no culto, motivava toda a congregação à leitura. Houve períodos em que eu lia a Bíblia diariamente e por horas, completando-a a cada três meses. Em muitas congregaçóes pentecostais, os jovens criam grupos de estudo e de oração, e dedicam-se muito à leitura e ao estudo, não só aos domingos no templo, mas como grupos de amigos. Em poucos anos, um novo converso pentecostal já terá carga de leitura bíblica corrida maior que a maioria dos outros cristãos a seu redor. Até aqui há uma semelhança com outros grupos de matriz norte-americana. Experiências especificamente mais "pentecostais" ocorriam após os momentos de leitura, e muitas vezes acontecem em meio à leitura, quando oraçóes espontâneas e experiências intensas de êxtases ou transe podem irromper. Os que observam os cultos públicos pentecostais costumam considerá-los barulhentos e efusivos. Os momentos de oração e contemplaçáo em privado ou em oraçôes de grupos, seja no templo a portas fechadas ou em lugares ermos, acabam sendo muito mais intensos (como as oraçóes em vigílias nas montanhas ou no templo durante horas da madrugada, às vezes amanhecendo o dia).
} 
espiritualidade pentecostal - sentir o texto e ouvi-lo falar. ${ }^{10}$ Assim, não se trata apenas de um livro (uma coisa), mas, performaticamente, é percebido como Deus falando-lhes por meio do texto (um Tu eterno e não uma coisa, no sentido relacional de Martin Buber, 2001). Por isso, há muitos casos de motivação interna para a alfabetização dos pentecostais via leitura bíblica. Nos programas sociais de inclusão pela leitura, a educação de adultos contou com forte presença pentecostal, motivados pela vontade de fazer sua própria leitura da Bíblia. ${ }^{11}$ Por Palavra de Deus, eles entendem mais que as letras do texto sagrado. Trata-se de "letras vivas", que dáo sentido à vida. É uma leitura com forte apelo devocional, que mexe com a orientação da vida presente e futura do sujeito. Antonio Paulo Benatte (2012) pode concluir:

De fato, como temos observado, os pentecostais constituem comunidades bibliocêntricas e bibliocráticas em que o Livro sagrado é regra de fé e conduta e fonte última de autoridade e legitimação; mesmo as interpretações divergentes só adquirem sentido quando referidos aos estilos, estratégias e esquemas interpretativos partilhados comunitariamente pelos leitores. A partir da leitura dos próprios textos - que contêm em si um "leitor implícito" e modelos de leitura ideal -, os protocolos e convençóes de leitura são comumente aceitos e reproduzidos em determinado tempo e espaço social, no âmbito de grupos e comunidades. A observação de esquemas, lógicas ou padróes não implica dizer que os leitores não participam criativamente da fabricação dos significados, mas que a produção de sentido nunca é um trabalho individual, e que, com efeito, o leitor nunca lê sozinho (Benatte, 2012: 26).

O cânon selecionado adquire certa normatividade para a vida do sujeito e para o ser igreja em comunidade. Os pregadores usam o mesmo expediente, havendo os que fazem uso de métodos exegéticos consagrados na literatura, mas também há espaço ou mescla-se com uma hermenêutica pentecostal, em que a leitura está sempre orientada para a açáo por meio do milagre (da ação direta do divino no indivíduo ou nas circunstâncias) que, em sua prática, se concebe como auxiliada pelo Espírito Santo, quem avivaria a Palavra. Nesse sentido, pode-se perceber outra característica

${ }^{10}$ A Reforma Protestante e mesmo em Lutero já enfatizavam esse caráter vivente da Bíblia. As passagens bíblicas eram entendidas como eventos vivos, aqui e agora pelo Espírito. Conforme aponta Timothy George (1994: 86), “a experiência é necessária para entender a Palavra”.

${ }^{11}$ Leda Paulani (2016, p. 135) afirma: "O conjunto de todos esses dados faz supor que boa parte da elevação do índice de leitura de livros não acadêmicos de 1,8 para 2,9 entre 2000 e 2015 deve-se à crescente importância das religióes pentecostais e/ou evangélicas no país nas últimas décadas". E esclarece: "É interessante notar que, considerando-se a composiçáo da amostra dessa pesquisa do ponto de vista da religião, $25 \%$ dos entrevistados declararam-se adeptos de religióes pentecostais ou evangélicas, justamente aquelas para as quais a leitura frequente da Bíblia coloca-se como obrigaçáo. Não por acaso, o número de livros religiosos, incluindo a Bíblia, lidos nos últimos três meses, gira em torno de 1,0 para os adeptos dessas religióes, sendo de 0,5 para os católicos, que constituem quase $60 \%$ da amostra”. 
dessa forma pentecostal de ler: uma leitura condicionada pelo ethos do grupo, que, por isso, pode prescindir de ater-se à tradiçáo e ao enquadramento da leitura pelo estudo formal da recepçáo do texto. Aqui, o texto interpela o sujeito e este, a partir do seu contexto, interage com a Bíblia, buscando uma direçáo/orientaçáo. Trata-se de um encontro "pessoal", de mútua interpelação, em que a Bíblia faz a funçáo de "sujeito", personificada como Palavra de Deus. Assim, o texto personificado fala diretamente ao leitor, promovendo momentos formadores em continuidade com o texto, mas também, como informa a Estética da Recepçâo, promovendo rupturas, pois a obra tem o poder de contrariar as expetativas do leitor e alterar seu comportamento. Com isso, por conta dessa radicalidade do texto bíblico e da polissemia que ele oferece na dinâmica do Espírito e pela vivência em comunidade e em situaçóes específicas, em algumas ocasiōes a leitura bíblica pentecostal poderá, simplesmente, ultrapassar as tradiçōes da Reforma e chegar a conclusōes diferentes. ${ }^{12}$

Outra característica marcante é ser uma leitura marcadamente subjetiva. Sabe-se que o leitor é um sujeito concreto inserido em um contexto também concreto, bem como suas experiências, que sáo igualmente concretas. Como observamos, o leitor náo é passivo. Ele constrói raciocínios e assume posiçóes, selecionando o quê apropriar-se da leitura (Cf. Leonel, 2010, p. 325) e, ao mesmo tempo, é interpelado pelo texto.

\section{Diferentes formas de ler a Biblia no Protestantismo}

As diferentes tradições da Reforma também fizeram suas leituras "particulares". As tradiçóes calvinistas, por exemplo, leem as Escrituras a partir da ideia da predestinação, criando seu próprio "cânon calvinista" dentro do cânon. Os luteranos e os demais leitores, enquanto tais, também fazem suas escolhas. Assim, não há uma leitura isenta e objetiva, como se um determinado grupo, usando instrumental adequado, conseguisse chegar ao "único" sentido possível ou correto, ou mesmo à "intenção do autor". Se considerarmos que há, como afirmou Paul Tillich (2000: 248), uma "tendência antimística" na igreja hodierna, que sempre teve reservas quanto às experiências ditas do Espírito (seja por conta da crítica implícita que esses movimentos representavam para a hierarquia eclesiástica, seja pelo caráter sectário de algumas dessas manifestaçôes ou, mesmo, pela falta de controle da instituiçáo sobre esse tipo de comportamento), o modo da leitura pentecostal não é visto como

\footnotetext{
${ }^{12}$ É o caso da doutrina pentecostal do batismo com o Espírito Santo, que não é endossada pela Reforma Protestante. De forma mais ampla, também não há consenso sobre os sacramentos ou as ordenanças, nem sobre os alcances da ação do Espírito, entre outros temas doutrinários.
} 
adequado pelas demais famílias cristãs, devido aos riscos que ele oferece para o corpus doutrinário.

$\mathrm{Na}$ Suécia, os pentecostais apareceram entre os batistas, sendo uma minoria frente os luteranos. Por conta das suas posiçôes doutrinárias e comportamentais, os pentecostais batistas suecos sofreram enfrentamento dos demais batistas, passando a ser a minoria da minoria. Nos EUA, o caso de William Seymor é emblemático. Filho de negros que haviam sido escravizados, ele experimentou a violência segregacionista dentro e fora do movimento nascente. Quando frequentou o instituto bíblico, tinha que assistir às aulas no corredor, porque era impedido de compartilhar a mesma sala de aula com os brancos (CAMPOS, 2005: 108). De fato, o Pentecostalismo pela dinâmica própria de movimento era muito mais flexível e inclusivo do que as instituições eclesiásticas estabelecidas, mas isso, por si só, não resolveria internamente os problemas sociais. O surgimento das Assembleias de Deus nos Estados Unidos deveu-se, em parte, a questóes raciais, constituindo-se em uma denominação de predomínio de brancos (Alencar, 2013). Em 1918, parte do movimento pentecostal brasileiro decidiu assumir o nome Assembleias de Deus. Mas as Assembleias brasileiras não imitarão o segregacionismo norte-americano, uma vez que, de fato, os pentecostais nessa regiáo ainda podem ser conhecidos como "a religião mais negra do Brasil” (Oliveira, 2005), o que indica que a recepção da Bíblia por essas minorias foi capaz de fundir os "horizontes de perspectivas" do autor-leitor em chave de esperança e de enfrentamento da realidade social.

Zwinglio Mota Dias (2011: 381) afirmou que os pentecostalismos, com sua ênfase na experiência e na emoção, teriam algo muito positivo para os demais protestantes e para os católicos, que seria "o desafio de uma revisão histórica de suas teologias e práticas pastorais que seja capaz de transformá-las novamente em comunidades acolhedoras e integradoras". A leitura bíblica pentecostal performática poderia ajudar nesse aspecto? Antonio Benatte (2012: 09) pondera, indicando que a leitura pentecostal estaria para além de mera leitura literal: "a noção de 'leitura literal' é teórica e empiricamente inadequada para compreender a complexidade da relação dos crentes com a Bíblia Sagrada”. No próximo e último tópico, buscamos caracterizar mais o tipo de leitura pentecostal.

\section{A Leitura Bíblica Pentecostal Performática}

Marius Nel (2015) aponta que o emblema da leitura bíblica pentecostal é supor uma relação direta com o Espírito Santo dando vida e esclarecendo a Escritura, seja 
por meio da pregaçáo no templo ou da leitura individual ou, ainda, coletiva. Por um momento, pode-se considerar que outras tradiçôes também o façam, como foi apontado em notas anteriores, envolvendo, por exemplo, Lutero e sua perspectiva da "Palavra viva". No entanto, para além da certeza da atuaçâo divina no interior do crente ("habitaçáo divina"), o que ainda estaria dentro de um padrão racionalista uma vez que há textos na Escritura que corroboram essa açáo divina e a lógica pode ser "eu creio porque está escrito" -, o pentecostal atribui essa ação divina a um agir especial do Espírito Santo. Como bem observou Kenner Terra (2015: 167-179), esse lugar teológico de produção de sentido para o pentecostal é o próprio êxtase. A leitura pentecostal se dá na relaçáo com o Espírito Santo e por meio de experiências extáticas, isto é, por meio de performances informadas pelo Espírito.

Nel afirma também:

\begin{abstract}
Argumentou-se que uma hermenêutica pentecostal enfatiza três elementos: a interrelação entre o Espírito Santo como Aquele que anima as Escrituras e capacita a comunidade crente. Para eles, a experiência de um encontro com Deus através do seu Espírito é imperativa, e a interpretação da informação contida na Bíblia é determinada pela sua práxis (Nel, 2015: 16). ${ }^{13}$
\end{abstract}

Kenneth Archer (2009) identificou três períodos da hermenêutica pentecostal, que ele denominou de pré-crítico (1900 a 1940), moderno (1940 a 1980) e contemporâneo (1980 até o presente). Apesar de referir-se à realidade norteamericana, essa classificação auxilia na compreensão de como o movimento pentecostal foi lidando com a leitura bíblica internamente, sem perder o lugar teológico predileto e característico da construção do seu pensamento, que é o êxtase, a experiência religiosa intensa ou, como preferem os pentecostais, na "presença do Espírito” - um lugar que em tese, está acessível aos que se dedicarem a encontrá-lo. Como essa relação com o Espírito não está atrelada à hierarquia da igreja, é possível a qualquer membro do grupo ter essa experiência de iluminação do Espírito ao ler as Escrituras. Está aqui seu potencial comunitário e leigo, portanto, com capilaridade muito maior do que outros grupos cristáos. Isto explicaria em parte como o fervor pentecostal não só condiciona a leitura bíblica, mas também impulsiona seus membros para o anúncio da sua fé (missão).

\footnotetext{
13 "It has been argued that a Pentecostal hermeneutics emphasises three elements: the interrelationship between the Holy Spirit as the One animating Scriptures and empowering the believing community. For them, the experience of an encounter with God through his Spirit is imperative, and interpretation of the information contained in the Bible is determined by their práxis" (tradução livre pelo autor).
} 
A leitura bíblica pentecostal performática parte de uma soma de linguagens (escrita, sonora, gestual, sensitiva) produzindo uma leitura vivificada ou uma leituraação. O leitor informado pela experiência pentecostal, usando de uma sensibilidade aguçada, além de ler, também vê, sente, escuta, imagina. ${ }^{14}$ No templo, a leitura performática envolveria toda a congregação, transformando os espectadores do culto em leitores performáticos, uma performance cênica ritual (para recordar a tipologia de Cohen, vista anteriormente). Essa linguagem híbrida da performance abre espaço para que essas comunidades pentecostais acessem novos conteúdos de fé ou que ressignifiquem os recebidos da tradição.

Essa leitura intensa pode ser uma compensação pelo iconoclastismo dos templos e das residências dos pentecostais. Sem imagens de escultura (ou pinturas de santos e personagens bíblicos que auxiliariam como mediadores) e sem templos decorados com obras de arte como nas igrejas católicas ou em algumas protestantes, aos pentecostais restou, como vimos, a dedicaçáo à experiência religiosa e o apego ao livro sagrado. A espiritualidade pentecostal demonstra também sua estima ao texto bíblico por meio da prática de portar um exemplar da Bíblia sempre em mãos, comportamento observado também em outros grupos evangélicos. Com o advento dos smartphones e dos tablets, o texto está à mão em várias versões e com múltiplas possibilidades de usos e aplicação. É comum um pentecostal ter vários exemplares da Bíblia e, com o crescimento do mercado editorial de cunho religioso, proliferaram edições de Bíblias comentadas com notas de rodapé e com estudos complementares segmentados por nichos de público - que são consumidas com voracidade. ${ }^{15}$

\section{Conclusóes}

A leitura bíblica pentecostal é um tipo de leitura performática que demostra uma postura de seguimento comprometido do grupo a partir do seu fervor religioso.

\footnotetext{
${ }^{14}$ Entre os pentecostais é muito valorizada, por exemplo, a prática de decorar e recitar versículos bíblicos, acentuando a localização do texto (livro, capítulo e versículo), como uma forma de aferir o nível de leitura do praticante. As pregaçôes, os debates, os aconselhamentos, para todas as açóes, são evocadas passagens do texto bíblico, que são usadas amplamente, aplicadas a contextos específicos e ressignificadas.

${ }^{15}$ Uma rápida olhada nas prateleiras das livrarias evangélicas ou nos sites das editoras servirá para constatar essa múltipla oferta de produtos. Como exemplo, podemos citar alguns títulos dessas Bíblias de estudo disponíveis no mercado: Bíblia Scofield, Bíblia Thompson, Bíblia Anotada de Charles Ryrie, Bíblia explicada McNair, Bíblia de Estudo Pentecostal, Bíblia Pentecostal para Meninas, Bíblia Plenitude, Bíblia Shedd, Bíblia da Mulher, Bíblia do Obreiro, Bíblia Palavras-chaves, Bíblia King James, Bíblia Cronológica, Bíblia de Aplicação Pessoal, Bíblia Apologética Cristã, Bíblia da Mamãe, Bíblia do Papai, Bíblia Bom Dia, Bíblia do Pescador, Bíblia das Descobertas (adolescentes), Bíblia de Estudo do Expositor, Bíblia do Pregador Pentecostal, Bíblia da Família, Bíblia de Estudo Almeida, Bíblia Missionária de Estudo, Bíblia de Estudo MacArthur, Bíblia de Estudo Princípio de Vida, Bíblia de Estudo de Genebra, Bíblia da Escola Bíblia, Bíblia do Líder Cristão, entre outras.
} 
A chave de acesso à Escritura se dá via experiência do Espírito Santo, uma subjetividade moldada em lugares extáticos ou situaçóes de êxtase. Por isso diz-se que os pentecostais se relacionam com a Escritura performaticamente, além de tratar o texto como Palavra viva, como um Tu-eterno, estabelecendo uma relaçáo de encontro do tipo Eu-Tu e náo Eu-coisa. A Bíblia como Palavra personificada é vivificada, falando ao fiel hoje, inclusive para questóes do dia a dia, adquirindo novos sentidos para o presente. Sendo uma religiosidade com fortes características de oralidade, a Palavra falada adquire contornos existenciais por meio desse tipo de leitura. Como propôs W. Iser, as interaçóes autor-texto-leitor podem produzir algo que até então inexistia.

Com o aumento do número de leitores de uma obra (leitor-autor), as releituras enriqueceram o texto e se plasmaram no ethos do grupo. Como bem observou Bastian (2013), o Pentecostalismo já modelou o Protestantismo latino-americano. Por outro lado, o gênero leitura performática não é uma exclusividade dos pentecostais. O que tem de específico é essa vinculação extática ao Espirito Santo, de tal modo condicionada pelo fervor religioso pentecostal que se manifesta em açóes, atitudes e até mesmo na estética destes grupos. Com essa "efervescência criadora de novas fórmulas" da religião (Durkheim), crenças e práticas religiosas, antigas ou novas, podem provocar sempre e de novo "novas explosóes de fervor religioso" (Berger). No Pentecostalismo, esse fervor produziu não só um aumento da carga de leitura bíblica (quantidade) e uma constância na frequência (disciplina), como também influenciou o modo de ler (hermenêutica).

A leitura bíblica pentecostal performatizada é um modo de leitura informado pelo Espírito Santo que assume potencialmente relaçóes criadoras entre autor-textoleitor da Bíblia por meio do êxtase e de transes, seja individual ou comunitariamente. A performance possibilita maior alcance e penetração por tratar-se de uma capacidade comunicacional mais eficaz que outros meios, uma vez que pode ir além da linguagem convencional, com o não verbal, com as emoçóes, com as memórias e com os sentidos. Como linguagem híbrida utiliza outras pontes entre o conteúdo das Escrituras e a vida prática dos fiéis, promovendo uma dialética que enriquece o texto e incorpora experiências pessoais (do grupo) como conteúdo.

A partir da Estética da Recepção, é possível afirmar também que a Bíblia, como obra literária, não estaria subjugada ao leitor pentecostal, como se este pudesse instrumentalizá-la meramente para interesses particulares. Como obra valiosa, o texto tem o poder de contrariar os horizontes de expectativas do leitor e interpelar o ethos do grupo. Assim, não é a leitura de um indivíduo isolado que lhe conferirá 
sentido autônomo, uma vez que a leitura é um fato social e dependente da comunidade para construir sentidos válidos. Da mesma forma, o ethos originário de uma obra é elemento importante e indicador nas interaçôes, já apontando seu sentido. A valorização do leitor e das interaçóes entre as subjetividades envolvidas é o que de fato permite a recepção e a coprodução do texto. Nesse sentido, em linguagem teológica, os leitores da Bíblia ao longo do tempo dão seguimento ao processo revelacional sob a força do Espírito, que continua ativo e operante. Os pentecostais representariam um grupo que faz desse axioma um modus operandi.

\section{Referências}

ADRIANO FILHO, J. Estética da recepção e hermenêutica bíblica. In: NOGUEIRA, P. A. S. (Org.). Linguagens da religião: desafios, métodos e conceitos centrais. São Paulo: Paulinas, ANPTECRE, 2012, pp. 165-190.

ALENCAR, G. F. Matriz pentecostal brasileira: Assembleias de Deus 1911-2011. Rio de Janeiro: Novos Diálogos, 2013.

ALTMANN, W. Lutero e libertação. São Leopoldo: Sinodal; São Paulo: Ática, 1994.

ALVES, R. O enigma da religião. 6. ed. Campinas: Papirus, 2007.

ARCHER, K. J. A Pentecostal Hermeneutic: Spirit, Scripture And Community. Cleveland: CPT Press, 2009.

AZEVEDO, L. Autoria e performance. In: Revista de Letras. v. 47, n. 2, 2007, pp. $133-158$.

BASTIAN, J. P., De los protestantismos históricos a los pentecostalismos latinoamericanos: análisis de una mutación religiosa. In: HUEZO MIXCO, Luis R. (Comp.). De las misiones de fe al neopentecostalismo. Génesis y evolución del protestantismo salvadoreño, desde el siglo XIX hasta el presente. San Salvador: Secretaría de Cultura de la Presidencia; Universidad Evangélica de El Salvador, 2013, pp. 29-52.

BEGUOCI. Brasil é o maior país pentecostal. In: Folha de São Paulo. Segunda-feira, 29 jan., 2007 [n.p.].

BENATTE, A. P. Os pentecostais e a Bíblia no Brasil. Aproximaçóes mediante a estética da recepção. In: Rever, 12, 01, 2012, pp. 9-30.

BERGER. A dessacralização do mundo: uma visão global. In: Religião e Sociedade, v. 21, n. 1, 2001, pp. 09-23. 
BUBER, M. Eu e tu. São Paulo. Centauro, 2001.

CAMPOS, B. Da reforma protestante à pentecostalidade da igreja: debate sobre o pentecostalismo na América Latina. São Leopoldo: Sinodal; Quito: Clai, 2002.

CAMPOS, B. Hermeneutica del Espiritu: Cómo Interpretar los Sucesos del Espíritu a la Luz de la Palabra de Dios. Ciudad de México: Kerigma, 2016.

CAMPOS, L. S. As origens norte-americanas do pentecostalismo brasileiro: observações sobre uma relação ainda pouco avaliada. In: Revista USP, 67, 2005, pp. 100-115.

CINTRA, M. Performances de fé: cultos da igreja pentecostal evangélica e ritos do candomblé. In: Curiosamente. [s.d]. Disponível em: http://www. http://curiosamente.diariodepernambuco.com.br/project/candomble-encontra-opentecostalismo-cultos-de-corpos-fe-e-fervores/.

COHEN, R. Performance como linguagem. Criação de um tempo-espaço de experimentação. São Paulo: Perspectiva, 2002.

DAYTON, D. Theological roots of Pentecostalism. Peabody, Massachusetts: Hendrickson, 1991.

DIAS, Z. M. Um século de religiosidade Pentecostal: algumas notas sobre a irrupção, problemas e desafios do fenômeno pentecostal. In: Horizonte, 9, 22, 2011, pp. 377-382.

ECO, U. A Obra Aberta. São Paulo: Perspectiva, 2010.

FURTADO, F. As origens da adoração cristã: o caráter da devoção no ambiente da igreja primitiva. São Paulo: Vida Nova, 2011.

GEORGE, T. Teologia dos reformadores. São Paulo: Vida Nova, 1994.

GLUSBERG, J. A arte da performance. São Paulo: Perspectiva, 1987.

ISER, W. O ato da leitura. v. 1. São Paulo: Ed. 34, 1999.

JAUSS, H. R. A história da literatura como provocação à ciência da literatura. São Paulo: Ática, 1994.

JAUSS, H. R. O prazer estético e as explicaçóes fundamentais da poiesis, aisthesis e Katharsis. In: LIMA, L. C. (Coord.). A literatura e o leitor: textos de estética da recepçáo. 2. ed. rev. e ampl. Rio de Janeiro: Paz e Terra, 2002, pp. 85-103. 
KEENER, C. S. Spirit Hermeneutics: Reading Scripture in Light of Pentecost. Grand Rapids, Michigan: Eerdmans, 2016.

LEONEL, J., História da leitura e protestantismo brasileiro: pastores presbiterianos como leitores. In: LEONEL, J. (Org.). Novas perspectivas sobre o protestantismo brasileiro. 2a ed., São Paulo: Paulinas; Fonte Editorial, 2010, pp. 325-370.

MARTIN, L. R. (Ed.) Pentecostal hermeneutics: a reader. Boston: Brill, 2013.

MENDONÇA, A. G. O celeste porvir: a inserção do protestantismo no Brasil. $3^{a}$ ed., São Paulo: Edusp, 2008.

NEL, M. Attempting to define a pentecostal Hermeneutics. In: Scriptura v. 114, n. 1, 2015, pp. 01-21.

NOEL, B. T. Pentecostal and Postmodern Hermeneutics: comparisons and Contemporary Impact. Eugene: Oregon: Wipf and Stock Publishers, 2010.

OLIVEIRA, M. D. A religião mais negra do Brasil: por que mais de oito milhóes de negros são pentecostais? São Paulo: Mundo Cristão, 2005.

PASSOS, J. D. Pentecostais: origem e começos. São Paulo: Paulinas, 2005.

PAULANI, L. M. Leitura e mercado de livros no Brasil: os resultados de duas diferentes pesquisas. In: FAILLA, Z. (Org.). Retratos da leitura no Brasil 4. Rio de Janeiro: Sextante, 2016, pp. 127-140.

RAVETTI, G. O corpo na letra: o transgênero performático. In: CARREIRA, A. et al. (Org.). Mediaçóes performáticas latino-americanas. Belo Horizonte: Faculdade de Letras, 2003.

STRONSTAD, R. The Charismatic Theology of St. Luke. Peabody, Massachusetts: Hendrickson Publishers, 1984.

TERRA, K. R. C. A leitura das narrativas sagradas: uma crítica à exegese tradicional à luz da Semiótica da Cultura e Teorias Narrativas. In: Horizonte, v. 14, n. 43, 2016, pp. 859-889.

TERRA, K. Extase, Pentecostes e unidade: desafios à luz das origens. In: OlIVEIRA, D. M. (Org.). Pentecostalismos e unidade. São Paulo: Fonte Editorial; FPLC; RELEP, 2015, pp. 167-179.

TILLICH, P. História do pensamento cristão. 2a ed., São Paulo: ASTE, 2000.

TILLICH, P. Teologia da cultura. São Paulo: Fonte Editorial, 2009. 
WAIZBORT, L. Introdução. In: WEBER, M. Os fundamentos racionais e sociológicos da música. São Paulo: Edusp, 1995, pp. 23-52.

WEBER, M. Reflexão intermediária - Teoria dos níveis e direçóes da rejeição religiosa do mundo. In: BOTELHO, A. (Org.). Essencial sociologia. São Paulo: Penguin Classics; Companhia das letras, 2013, pp. 505-552.

WITT, J. Sociologia. 3. ed. Porto Alegre: McGraw-Hill, 2016.

ZILBERMAN, R. Estética da recepção e história da Literatura. São Paulo: Ática, 1989.

Recebido: 06/04/2017

Aprovado: 16/06/2017 